\title{
Area protection may reduce salmon louse infection risk to wild salmonids
}

\author{
Pål Arne Bjørn ${ }^{1,2, *}$, Rolf Sivertsgård ${ }^{3}$, Bengt Finstad ${ }^{4}$, Rune Nilsen $^{1,2}$, \\ Rosa Maria Serra-Llinares ${ }^{1,2}$, Roar Kristoffersen ${ }^{3}$ \\ ${ }^{1}$ Nofima Marine, 9291 Tromsø, Norway \\ ${ }^{2}$ Institute of Marine Research, 58171 Bergen, Norway \\ ${ }^{3}$ Norwegian College of Fishery Science, University of Tromsø, 9037 Tromsø, Norway \\ ${ }^{4}$ Norwegian Institute for Nature Research (NINA), 7485 Trondheim, Norway
}

\begin{abstract}
Salmon louse Lepeophtheirus salmonis Krøyer infection levels in both wild sea trout Salmo trutta L. and sentinel Atlantic salmon Salmo salar L. smolts were investigated inside and outside a temporary protected zone with limits on fish farming in the intensively farmed Romsdalsfjord system. Wild sea trout outside the protected zone had higher prevalence and significantly higher abundances than those inside the zone. Furthermore, sentinel caged Atlantic salmon smolts confirmed significant differences in infection pressure: Eresfjord (non-farmed inner part of the protected zone) had the lowest infection risk, a moderate risk was found in Langfjord (intermediately farmed middle part of the protected zone), while Karlsøyfjord (intensively farmed area outside the protected zone) had the highest infection risk. No clear bias between the near-shore and pelagic areas of the fjord were found, although significant differences between pelagic and near-shore cages were occasionally observed. Results show that small sentinel cages can be used as an alternative method to monitor the infection pressure in a fjord system. Overall, our results indicate that wild salmonids may benefit from the protection zone. However, the infection level on wild sea trout inside the temporary protected zone was higher compared to completely farm-free fjords in Norway, and infection levels likely to have a negative physiological impact on wild sea trout were found. This may indicate that the zone is too small to have the necessary protective effect against salmon lice.
\end{abstract}

KEY WORDS: Wild salmonids $\cdot$ Salmon lice $\cdot$ Norwegian salmon fjords $\cdot$ Management $\cdot$ Aquaculture

Resale or republication not permitted without written consent of the publisher

\section{INTRODUCTION}

Many sea trout Salmo trutta L. stocks in Norway, Ireland and Scotland have experienced annual salmon louse Lepeophtheirus salmonis Krøyer epidemics during the latest decade (e.g. Bjørn et al. 2001, Butler \& Watt 2003, Gargan et al. 2003). This is probably a consequence of increased salmon farming activity in fjords and coastal areas (Tully \& Nolan 2002, Heuch et al. 2005, Boxaspen et al. 2007). Within a salmon farm, or within a salmon farming area, the concentration of potential hosts is much larger than in areas without farms (Heuch \& Mo 2001). The increased salmon louse production in farmed fish has been suggested to contribute to high infection levels in wild fish (Bjørn et al. 2001, Butler \& Watt 2003,
Gargan et al. 2003, Heuch et al. 2005, Krkošek et al. 2005, Boxaspen et al. 2007). Due to the year-round presence of farmed salmon in coastal waters and fjords, high louse production can also occur during late winter and spring time, when wild hosts are scarce (Heuch \& Mo 2001, Heuch et al. 2005, Stien et al. 2005). Heavy louse infections can cause particularly severe physiological disturbances in naïve migrating salmonid smolts (Grimnes \& Jakobsen 1996, Bjørn \& Finstad 1997, Finstad et al. 2000, Wagner et al. 2003, 2004, 2008, Wells et al. 2006). Annual salmon louse epidemics have therefore been blamed for the collapse of some wild salmonid stocks in fjords and coastal areas with heavy fish farming activity (e.g. Bjørn et al. 2001, Butler \& Watt 2003, Gargan et al. 2003, Krkošek et al. 2005, 2007). 
The Norwegian authorities have taken several measures in response, to reduce the infection pressure in fjords with intensive salmon farming activity (DN 1993, Fiskeridirektoratet 1996, NOU 1999, Heuch et al. 2005, DKMD 2006, DKF and Kystdepartementet 2009). Key among these measures was the establishment of temporary protected zones (DN 1993, Fiskeridirektoratet 1996) in certain areas close to important Norwegian salmon rivers, and the more recent establishment of numerous 'Norwegian Salmon Fjords', very similar in nature to the temporary protected zones, but with a more permanent character. The aim of both initiatives is to protect wild Atlantic salmon Salmo salar L., sea trout Salmo trutta L. and Arctic charr Salvelinus alpinus L. from different types of harmful interaction with cultured salmonids (NOU 1999, DKMD 2002, 2006). Their main purpose, besides reducing the numbers of escaped farmed salmon in these fjords, is to prevent the spread of salmon lice from farmed to wild salmonids (DN 1993, Fiskeridirektoratet 1996, NOU 1999, DKMD 2002, 2006). Within a temporary protected zone or a Norwegian Salmon Fjord, no new fish farms are allowed to be established. In addition, the fish farms already established have to comply with a strict operational regime, including compulsory delousing if the salmon louse infection level in farmed fish reaches a certain threshold level (NOU 1999, Heuch et al. 2005, DKMD 2006). Therefore, wild salmonids inside a protected zone are expected to have lower louse infection levels than fish outside a protected zone, even within the same fjord system.

The present study was initiated to investigate possible differences in salmon lice infection pressure inside and outside a temporary protected zone in a large Norwegian fjord system. This was done by gill-netting sea trout inside (Eresfjord) and outside (Karlsøyfjord) a temporary salmon farming protected zone in the intensively farmed Romsdalsfjord system, mid-Norway. In addition, hatchery-reared Atlantic salmon smolts in sentinel cages were used to study possible differences in infection pressure in different sections of the fjord system (Eresfjord, Langfjord and Karlsøyfjord), as well as between near-shore areas (where sea trout feed) and pelagic areas (where Atlantic salmon post-smolts migrate to) (e.g. Thorstad et al. 2004, Finstad et al. 2005, 2007).

\section{MATERIALS AND METHODS}

Study area. Eresfjord, Langfjord and Karlsøyfjord are 3 connected fjord areas in the Romsdalsfjord system $\left(62^{\circ} 40^{\prime} \mathrm{N}, 8^{\circ} 10^{\prime} \mathrm{E}\right)$ in Møre and Romsdal counties, mid-Norway (Fig. 1). The Romsdalsfjord system has intensive salmon farming activity. Most of the fish farms are localized in the outer part of the Romsdalsfjord system, a few farms are localized in the middle part (Langfjord), and none are in the innermost part (Eresfjord) (Fig. 1, statistics based on the Norwegian Fishery Directorate). The inner half (Langfjord and Eresfjord) of the system has been incorporated into a temporary protected zone (DN 1993, Fiskeridirektoratet 1996, DKMD 2002, 2006). Many rivers with anadromous populations of wild sea trout Salmo trutta and Atlantic salmon Salmo salar enter both outer and

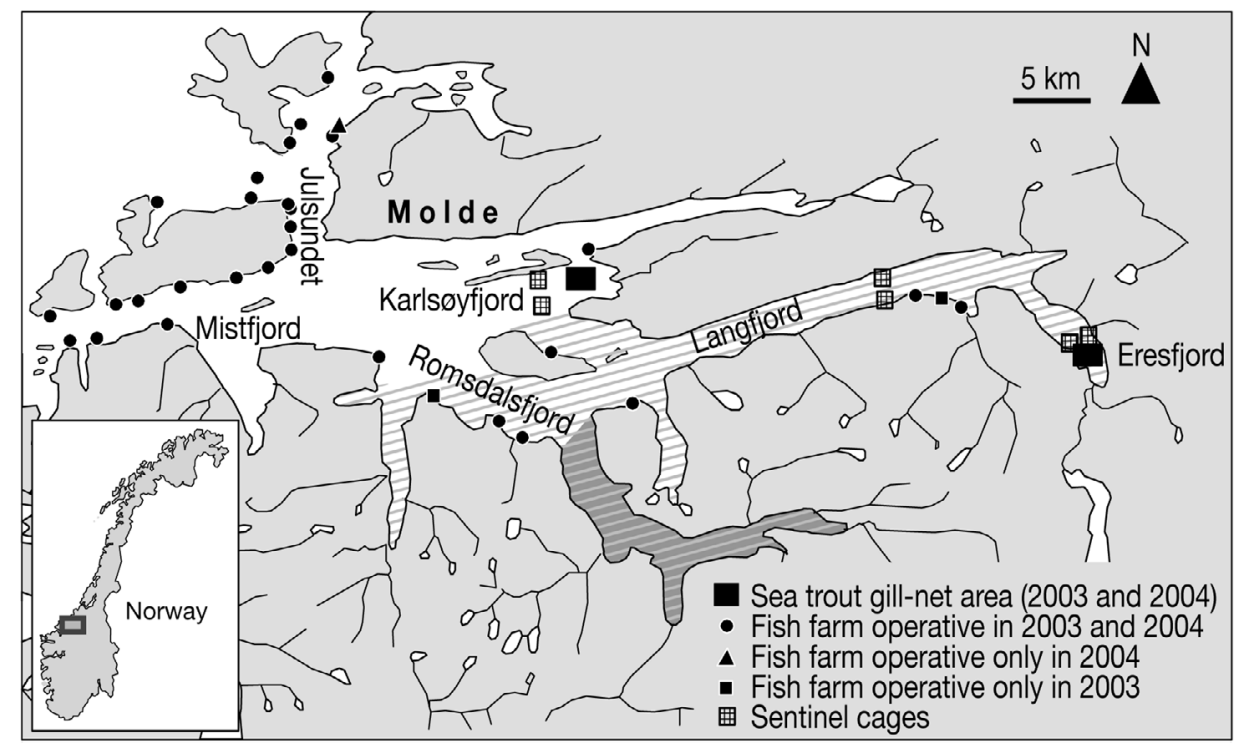

Fig. 1. Romsdalsfjord system, Norway $\left(62^{\circ} 40^{\prime} \mathrm{N}, 8^{\circ} 10^{\prime} \mathrm{E}\right)$. Hatched area: temporary salmon farming protection zone; dark grey: new National Salmon Fjord of Isfjord, which replaced the temporary protected zone of Romsdalsfjord, Langfjord and Eresfjord in 2006 (DKMD 2006) 
inner parts of the Romsdalsfjord system (Jensen et al. 2008). Most of the sea trout at sea in Norway feed close to their native rivers, while Atlantic salmon smolts rapidly migrate throughout the whole fjord system (Berg \& Berg 1987, Thorstad et al. 2004, 2007, Finstad et al. 2005). Thus, the different salmonid populations in this fjord system are probably exposed to different salmon louse Lepeophtheirus salmonis infection pressure in different sections of the fjord system. Sea trout were used as a model species, and a comprehensive 2 yr gill-net sampling programme was initiated both inside (Eresfjord) and outside (Karlsøyfjord) the fish farming temporary protected zone to study spatiotemporal differences in salmon louse infection pressure and the effect of area protection (see Fig. 1 for protected areas). However, different salmon louse abundances on wild sea trout at different localities can also be explained through horizontal dispersal of infective louse stages (Heuch et al. 2005, Asplin et al. in press), by different louse levels in farms operating in different sections of the fjord, or by sea trout undertaking long-distance sea migrations (Berg \& Jonsson 1990) and having spent parts of their seawater journey in higher risk areas. In addition to sampling wild sea trout, sentinel cages with hatchery-reared salmon were therefore deployed both near-shore and pelagically (Fig. 1) in the different fjord sections (Eresfjord, Langfjord and Karlsøyfjord). Furthermore, data on water parameters and infection level, as well as on the standing stock of farmed salmon, were also gathered from these fjord sections (Fig. 1).

Gill-net sampling and analyses. Wild sea trout were regularly sampled, both inside (Eresfjord) and outside (Karlsøyfjord) the protected area, by floating gill-nets from May to August in 2003 and 2004, according to methods described by Bjørn et al. (2001). Most salmonid smolts descend the rivers during May in this fjord system (Jensen et al. 2008), and the sampling regime therefore covered most of the seawater phase. Sampled fish were gently cut out of the nets and placed in individual plastic bags and frozen for later examination. In the laboratory, captured fish were thawed, measured to the nearest millimetre (fork length, $L_{\mathrm{F}}$ ), weighed to nearest $0.1 \mathrm{~g}$ and examined under an illuminated magnifying glass $(10 \times)$. Salmon louse stages were identified according to Johnson \& Albright (1991) and Schram (1993). Temperature and salinity were measured on each sampling occasion in both fishing areas from the surface layer $(0.5 \mathrm{~m})$ down every $0.5 \mathrm{~m}$ to a depth of $5 \mathrm{~m}$ using a CTD meter.

Sentinel cage deployment and analysis. A total of 12 sentinel cages with hatchery-reared Atlantic salmon were used in our study in 2004. This method has been used previously to study spatio-temporal salmon lice infection pressure (Costelloe et al. 1995). However, the design and size of the cages are new and have been strongly modified to make the method more operational. Two cages were located $<20 \mathrm{~m}$ from each other in both near-shore and pelagic areas of Eresfjord, Langfjord and Karlsøyfjord (Fig. 1); data were later pooled due to insignificant differences in louse abundance (Mann-Whitney $U$-test; $\mathrm{p}>0.05$ ). Near-shore cages were situated $<50 \mathrm{~m}$ from the shoreline. Pelagic cages were deployed approximately in the middle of the fjord, with an average distance of $1 \mathrm{~km}$ from the near-shore cages. The cage rig (Fig. 2) consisted of a $25 \mathrm{~kg}$ anchor in near-shore areas and a $100 \mathrm{~kg}$ iron plate in pelagic areas. A steel chain was attached to the anchor, and a nylon rope connected the end of the chain to a 75 inch $(\sim 190 \mathrm{~cm})$ floating buoy at the water surface. The cage was circular, $0.8 \mathrm{~m}$ wide and $0.9 \mathrm{~m}$ high, and it was covered with a knotless mesh $(1 \times$ $1 \mathrm{~cm}$ ) that had an opening on the top. The cage was connected directly to the anchor rope, $1 \mathrm{~m}$ under the buoy, through the upper and lower polyethylene rings (Fig. 2). The depth for cages (1 to $2 \mathrm{~m}$ below the surface) was based on observations about the depth which salmon lice (Heuch 1995, Heuch et al. 1995) and wild salmonid post-smolts (Thorstad et al. 2004, 2007, Rikardsen et al. 2007, Davidsen et al. 2008) prefer in the water column. The rope used to close the upper opening of the cage was also connected directly to the

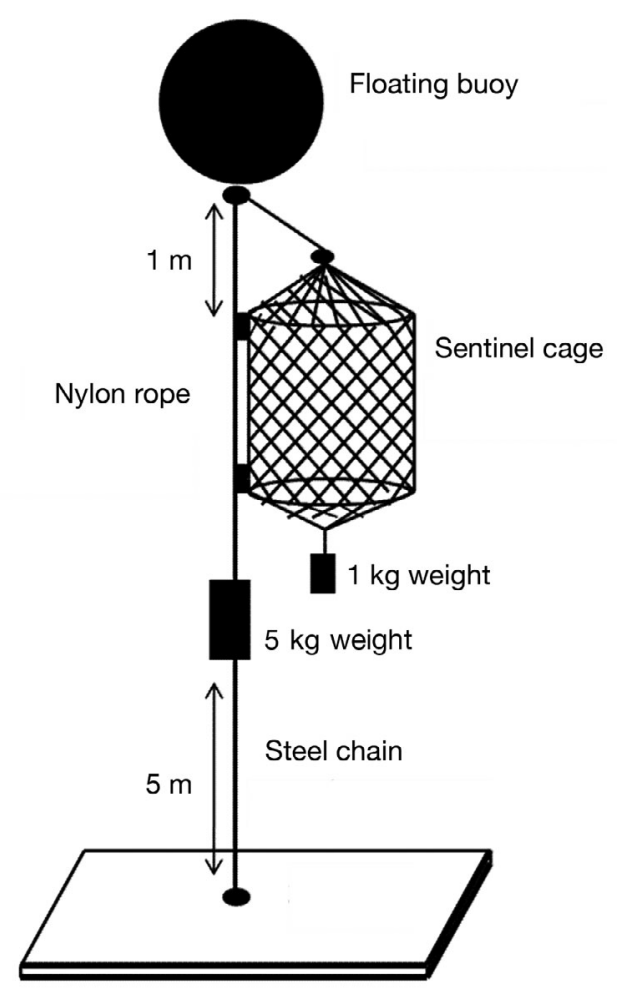

Fig. 2. Construction of a sentinel cage mooring (lengths not to scale) 
floating buoy. This, together with a $1.0 \mathrm{~kg}$ weight connected to the centre bottom of the cage, extended the cage. To keep the cage in a vertical position, a $5.0 \mathrm{~kg}$ weight was connected to the anchor rope $2 \mathrm{~m}$ below the cage.

Twenty-five 2 yr old first generation hatchery-reared Atlantic salmon smolts from the Statkraft hatchery in Eresfjord were placed in each of the cages. Clean cages were used in every trial. A seawater tolerance test (Blackburn \& Clarke 1987) on 6 May 2004 revealed plasma chloride levels of $147 \mathrm{mM}$, indicating that the fish had smoltified and were ready to be released into seawater (Sigholt \& Finstad 1990). The fish were not fed during the $24 \mathrm{~h}$ preceding each trial, to reduce handling and transport stress (Wedemeyer 1997, Portz et al. 2006). The smolts were transported to cages in oxygenated saltwater-filled (salinity $34 \mathrm{ppt}$ ) plastic bags $(500 \times 900 \mathrm{~mm})$. The bags were ice cooled with ice blocks around the bags during transportation, and the bags were covered so the fish were transported in darkness to reduce transport stress (Wedemeyer 1997 , Portz et al. 2006). The first trial was performed in Weeks 19 to 21 (early May), and the second trial was performed from Week 22 to Week 24 (May/June) in 2004. After $14 \mathrm{~d}$ in sentinel cages at sea, all fish were gently removed from the cages, killed by a blow to the head, placed in individual plastic bags and frozen for later lice inspection in the laboratory (Johnson \& Albright 1991, Schram 1993). The fish were measured $\left(L_{\mathrm{F}}\right)$ to the nearest millimetre and weighed to the nearest $0.1 \mathrm{~g}$.

Fish farm sampling and analysis. Information was obtained from almost all salmon farms operating in the fjord system (Fig. 1) on the average number of sexually mature female lice and on the total number of salmon held in sea cages. This information included all farms inside the protected zone and $\sim 90 \%$ of the farms outside the protected zone, and was obtained from the Norwegian Food Safety Authority (www.mattilsynet. no). The infection data are based on louse counts from farmers or veterinarians on a random sample of 20 fish from 2 cages in each farm every second week during the investigated period. Infection for approximately every month in each fish farm is a mean of 2 counting turns. This compulsory lice monitoring level follows the procedures from the Norwegian Food Safety Authority (Heuch et al. 2005). We used the abundance of sexually mature females and the number of farmed salmon to assess the possible louse infection pressure from fish farms (Heuch \& Mo 2001) in different sections (Eresfjord, Langfjord and Karlsøyfjord) of the Romsdalsfjord system.

Data analysis. Bush et al. (1997) have recommended the ecological terms used in the present study: prevalence, abundance and intensity. The degree of aggre- gation of parasites is measured by the variance $\left(s^{2}\right)$ to mean $(\bar{x})$ ratio $\left(s^{2} \bar{X}^{-1}\right)$, which seems most reliable when comparing samples having different prevalence or means (Scott 1987). This ratio is $<1$ if the parasites are evenly distributed, $\sim 1$ if the distribution is random and $>1$ if the parasites are aggregated. If aggregation is detected, mean values (abundance and intensity) might be influenced by the presence of outliers. In this case, a median distribution would preferably be used to show the infection, as this parameter is less affected by the presence of extreme values.

Data collected from gill-netting of wild sea trout comprised 3 to 4 different sampling points (weeks) per year and 2 locations (inside and outside the protection area). The Kruskal-Wallis test was used to test for significant differences in lice infection between weeks inside each location. Differences between locations were investigated week by week using the Mann-Whitney $U$-test.

Differences in lice infection between sentinel cages deployed in the outer (Karlsøyfjord), middle (Langfjord) and inner (Eresfjord) part of the fjord were analyzed using Kruskal-Wallis tests for near-shore and pelagic cages separately. Post hoc analyses of significant Kruskal-Wallis tests were done using pairwise Mann-Whitney $U$-tests. Differences between nearshore and pelagic cages deployed in the same area were also analyzed using the Mann-Whitney U-test.

We performed statistical analyses with SPSS 15.0, and a probability level of $\leq 0.05$ was considered significant. The significance levels of the post hoc MannWhitney $U$-tests were set at a lower threshold ( $\mathrm{p}<$ $0.05 / 3=0.017$ ) to account for multiple comparisons. The GPS (global positioning system) position of every fish farm in the entire fjord system was gathered from the Norwegian Fishery Directorate. We used these GPS positions in OziExplorer 3.90 GPS Mapping Software to find the location of fish farms.

\section{RESULTS}

\section{Water parameters}

In 2003, mean water temperature in the upper $5 \mathrm{~m}$ of the gill-netting area in Eresfjord (protected area) ranged from 8 to $20^{\circ} \mathrm{C}$. Temperature was lowest in spring and rose during summer. Mean salinity ranged from 20 to $24 \mathrm{ppt}$, again lowest in spring and rising during summer. In Karlsøyfjord (unprotected area), mean temperature $\left(10\right.$ to $16^{\circ} \mathrm{C}$ ) and mean salinity (26 to 29 ppt) were slightly higher (Table 1). In 2004, mean salinity in the upper $5 \mathrm{~m}$ ranged from 20 to $23 \mathrm{ppt}$ and temperature from 12 to $20^{\circ} \mathrm{C}$ in Eresfjord. Again, lowest salinity and temperature were found in spring 
(Table 1). In Karlsøyfjord, salinity was higher (around 29 ppt on all occasions), and temperature increased from $11^{\circ} \mathrm{C}$ in spring to $19^{\circ} \mathrm{C}$ in summer (Table 1).

\section{Infection in wild sea trout}

Inside the protected area

Data from 118 and 99 wild sea trout Salmo trutta captured inside the protected area (Eresfjord) during the 2003 and 2004 surveys (respectively) are given in Table 1. In both years, the abundance of salmon lice Lepeophtheirus salmonis recorded in the area varied significantly throughout the sampling periods (KruskalWallis tests; $\mathrm{p}=0.000$ ). In May (Week 21), a low to moderate percentage ( $4 \%$ in 2003 and $28 \%$ in 2004) of all the sea trout captured in the area carried salmon lice, with intensities of between 3 and 5 lice per infected fish. From May to July, prevalence increased progressively and reached 67 and $77 \%$ in 2003 and 2004, respectively. In Week 32 (2004) prevalence was slightly lower (72\%) than in Week 28. In 2003, highest abundance (mean \pm SD: $20.5 \pm 35.5$ ) and inten- sity $(30.2 \pm 40.1)$ were recorded in Week 28 , together with a high range and variance to mean ratio, showing an aggregation of lice within the host population. In 2004, the highest prevalence was found in Week 28, but the highest abundance (12.2 \pm 23.5$)$ and intensity $(19 \pm 27.2)$ occurred in Week 24, as did the highest range and variance to mean ratio.

The infection in May 2003 consisted of $14 \%$ larvae, $43 \%$ preadult and $43 \%$ adult lice (Fig. 3a). There was a re-infestation of larvae (91\% of total infection) in June, followed by a higher degree of adult stages in July (52\% larvae, $32 \%$ preadults and $16 \%$ adults of total infection). In May 2004, the infection consisted mostly of larvae $(70 \%)$ and some preadult and adult lice (Fig. 3b). A high proportion of larvae (94\%) was also found in June. In July, more preadult (32\%) and adult stages ( $7 \%$ ) were found. In August, the sea trout were mostly infected with adult and preadult stages.

\section{Outside the protected area}

Table 1 shows data from 42 and 43 sea trout captured in Karlsøyfjord (outside the protected zone) in

Table 1. Infection parameters for sea trout Salmo trutta caught in different weeks inside (Eresfjord) and outside (Karlsøyfjord) the protected zone in 2003. Prevalence: percentage infected of the total number of fish; abundance: mean no. of salmon lice Lepeophtheirus salmonis on all fish sampled; intensity: mean no. of salmon lice on infected fish only; IQR: interquartile range. Fish mass, length, abundance and intensity are given as means $( \pm \mathrm{SD})$; median, IQR, range and variance to mean ratio are intensity values; salinity (ppt) and temperature $\left({ }^{\circ} \mathrm{C}\right)$ at fishing locations are also given

\begin{tabular}{|c|c|c|c|c|c|c|c|c|}
\hline & \multirow[b]{2}{*}{ Week 21} & \multicolumn{2}{|c|}{ Eresfjord } & \multirow[b]{2}{*}{ Week 32} & \multirow[b]{2}{*}{ Week 21} & \multicolumn{2}{|c|}{ Karlsøyfjord } & \multirow[b]{2}{*}{ Week 32} \\
\hline & & Week 24 & Week 28 & & & Week 24 & Week 28 & \\
\hline \multicolumn{9}{|l|}{2003} \\
\hline Salinity (ppt) & $20.4 \pm 3.4$ & $24.6 \pm 4.4$ & $23.6 \pm 6.5$ & & $25.9 \pm 0.4$ & $27.5 \pm 1.6$ & $28.7 \pm 0.4$ & \\
\hline Temperature $\left({ }^{\circ} \mathrm{C}\right)$ & $8.0 \pm 0.2$ & $12.4 \pm 1.2$ & $15.3 \pm 0.52$ & & $10.8 \pm 0.2$ & $13.2 \pm 0.6$ & $16.0 \pm 0.2$ & \\
\hline Number of fish & 48 & 43 & 27 & & 15 & 19 & 8 & \\
\hline Fish mass (g) & $155 \pm 137$ & $97 \pm 69$ & $168 \pm 153$ & & $425 \pm 325$ & $364 \pm 194$ & $453 \pm 368$ & \\
\hline Fish length (mm) & $25 \pm 6$ & $21 \pm 4$ & $24 \pm 6$ & & $33 \pm 7$ & $32 \pm 6$ & $32 \pm 10$ & \\
\hline Prevalence (\%) & 4 & 37 & 67 & & 73 & 100 & 88 & \\
\hline Abundance & $0.2 \pm 0.7$ & $8.9 \pm 3.0$ & $20.5 \pm 35.5$ & & $3.3 \pm 5.7$ & $52.8 \pm 53.1$ & $19.6 \pm 15.5$ & \\
\hline Intensity & $3.5 \pm 0.7$ & $23.9 \pm 45.7$ & $30.2 \pm 40.1$ & & $4.6 \pm 6.2$ & $52.8 \pm 53.1$ & $22.4 \pm 14.4$ & \\
\hline Median & 3.5 & 9.5 & 8.5 & & 3 & 38 & 18 & \\
\hline IQR & 1 & 19 & 45.3 & & 2 & 37 & 30 & \\
\hline Range & $3-4$ & $1-186$ & $1-143$ & & $1-23$ & $1-130$ & $4-40$ & \\
\hline Variance to mean ratio & 0.1 & 87.1 & 53.2 & & 8.5 & 53.4 & 9.2 & \\
\hline \multicolumn{9}{|l|}{2004} \\
\hline Salinity (ppt) & $20.5 \pm 3.5$ & $21.2 \pm 4.1$ & $23.4 \pm 5.5$ & - & $29.4 \pm 0.2$ & $29.5 \pm 0.3$ & $29.1 \pm 0.8$ & - \\
\hline Temperature $\left({ }^{\circ} \mathrm{C}\right)$ & $12.0 \pm 0.7$ & $13.7 \pm 0.2$ & $19.8 \pm 1.85$ & - & $10.9 \pm 0.1$ & $13.2 \pm 0.4$ & $19.3 \pm 0.2$ & - \\
\hline Number of fish & 43 & 25 & 13 & 18 & 6 & 21 & 9 & 7 \\
\hline Fish mass $(\mathrm{g})$ & $267 \pm 304$ & $383 \pm 276$ & $196 \pm 163$ & $427 \pm 413$ & $490 \pm 664$ & $363 \pm 189$ & $176 \pm 133$ & $322 \pm 428$ \\
\hline Fish length (mm) & $27 \pm 7$ & $27 \pm 7$ & $25 \pm 6$ & $30 \pm 9$ & $31 \pm 11$ & $40 \pm 39$ & $38 \pm 43$ & $29 \pm 8$ \\
\hline Prevalence (\%) & 28 & 64 & 77 & 72 & 83 & 86 & 89 & 71 \\
\hline Abundance & $1.2 \pm 2.5$ & $12.2 \pm 23.5$ & $10.7 \pm 13.4$ & $5.7 \pm 6.4$ & $5.7 \pm 4.4$ & $18.2 \pm 20.1$ & $27.9 \pm 42.9$ & $2.4 \pm 2.6$ \\
\hline Intensity & $4.3 \pm 3.1$ & $19.0 \pm 27.2$ & $13.9 \pm 13.8$ & $7.9 \pm 6.3$ & $6.8 \pm 3.8$ & $21.3 \pm 20.2$ & $31.4 \pm 44.5$ & $3.4 \pm 2.5$ \\
\hline Median & 3.5 & 5.5 & 10 & 7 & 7 & 17 & 10.5 & 4 \\
\hline IQR & 6.8 & 34.2 & 19.8 & 7.5 & 7.5 & 14 & 58 & 4.5 \\
\hline Range & $1-9$ & $1-96$ & $1-44$ & $2-24$ & $2-11$ & $1-93$ & $3-123$ & $1-7$ \\
\hline Variance to mean ratio & 2.2 & 39.1 & 13.8 & 5 & 2.2 & 19.1 & 63.2 & 1.9 \\
\hline
\end{tabular}




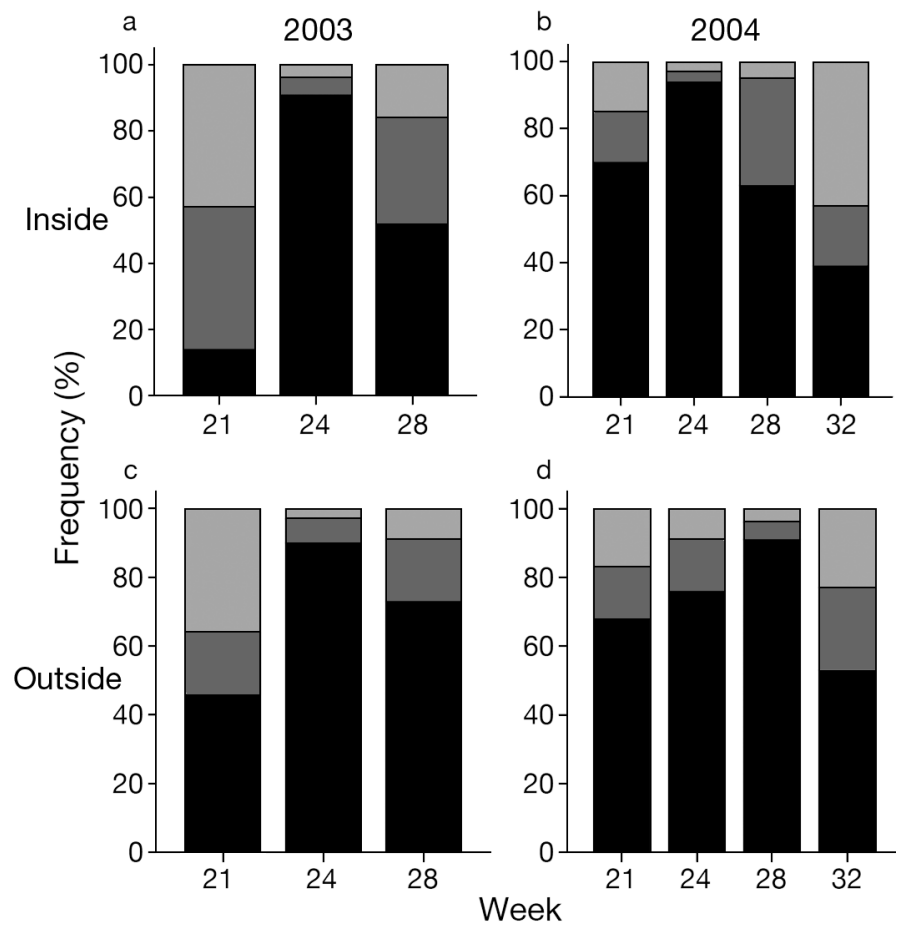

Fig. 3. Lepeophtheirus salmonis infecting Salmo trutta. Frequency distribution of different developmental stages of salmon lice on infected fish sampled inside and outside the protective zone (Eresfjord) in different weeks in 2003 and 2004. Black: all chalimus stages of larvae combined; dark grey: preadult males and females; light grey: adult males and females

2003 and 2004, respectively. In both years, abundance of sea lice varied significantly between the sampling weeks (Kruskal-Wallis tests; $\mathrm{p}=0.000$ for 2003; $\mathrm{p}=$ 0.020 for 2004) in this area. Prevalence of the salmon louse was 73 and $83 \%$ in May 2003 and 2004, respectively, with a mean intensity of 4 to 7 lice per infected fish (Table 1). In June 2003, $100 \%$ of the fish were infected, with a mean $( \pm \mathrm{SD})$ intensity of $52.8 \pm 53.1$ lice per fish. In 2004, the highest prevalence (89\%) and intensity $(31.4 \pm 44.5)$ were recorded in July (Week 28), together with a high range and variance to mean ratio.

In May 2003, the fish were infected mainly with larvae $(46 \%)$ and adult (36\%) louse stages (Fig. 3c). The infection peak in June showed that there had been a new infection inside Karlsøyfjord, and $90 \%$ of the louse population were larval stages, $7 \%$ were preadults and only $3 \%$ were adults. The high proportion of larvae $(73 \%)$ continued in July, together with $17 \%$ preadult and $10 \%$ adult lice. The fish caught in May 2004 were mostly infected with larvae, but also some preadult and adult stages were found (Fig. 3d). A high dominance of larval stages was also observed in June and July, while more preadult and adult lice were observed in August.

\section{Comparison infection inside and outside the protected area}

High variance to mean ratio were recorded during the weeks of highest infection in both Eresfjord and Karlsøyfjord. Median distribution was therefore used to better describe the infection pattern in the sea trout populations inside and outside the protected area in both 2003 (Fig. 4a) and 2004 (Fig. 4b). In 2003, lice infection during May and June (Weeks 21 and 24) was

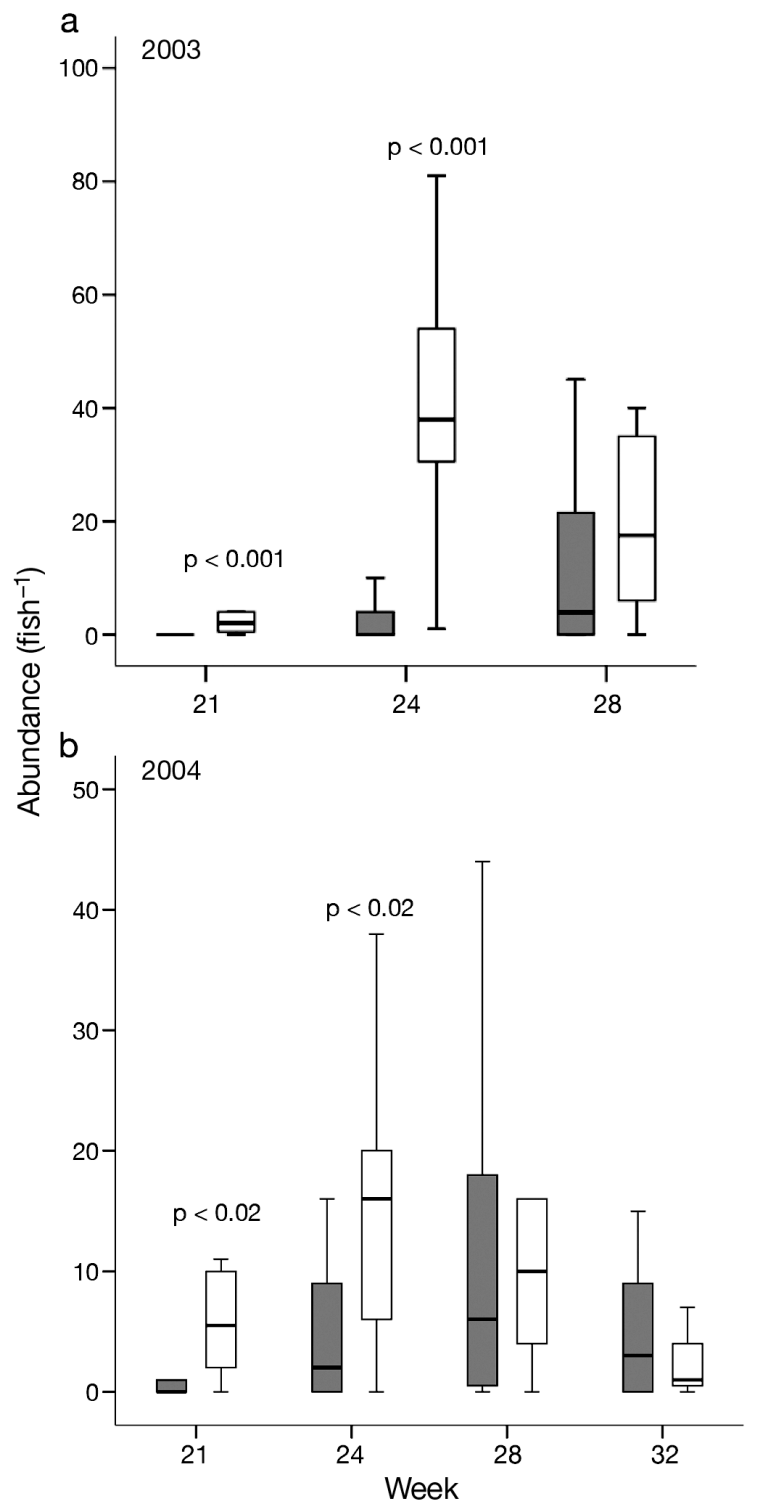

Fig. 4. Lepeophtheirus salmonis infecting Salmo trutta. Boxand-whiskers plot showing the number of lice per fish in all fish sampled outside ( $\square$, Karlsøyfjord) and inside ( $\square$, Eresfjord) the protected zone on different sampling occasions in 2003 and 2004. Horizontal lines: medians; bottom and top of boxes: 25 th and 75th percentiles; whiskers: largest and smallest observed values that are not outliers; $\mathrm{p}$-values (Mann-Whitney $U$-test) are given when significant differences were detected 
significantly higher in Karlsøyfjord (Mann-Whitney $U$ tests; $\mathrm{p}=0.000$ ) (Fig. 4a). In Week 28, abundance in Karlsøyfjord still remained higher than in Eresfjord, but no significant difference was found $(p=0.225)$. The same pattern occurred in 2004. During Weeks 21 and 24, Karlsøyfjord showed a significantly higher abundance (Mann-Whitney $U$-tests; $\mathrm{p}=0.002$ for Week 21 and $\mathrm{p}=$ 0.018 for Week 24) compared to Eresfjord (Fig. 4b). In Week 28, abundance in Karlsøyfjord started decreasing, while it was still increasing in Eresfjord, and the difference between locations was no longer significant $(p=0.492)$. Abundance in Eresfjord was slightly higher than in Karlsøyfjord during Week 32, but no significant difference was detected $(p=0.312)$.

\section{Infections in hatchery-reared Atlantic salmon post-smolts in sentinel cages}

In the first trial, the abundance of sea lice was significantly different between the 3 near-shore areas along the fjord (Kruskal-Wallis test; $p=0.000$ ) (Fig. 5a). The fish in the near-shore cages in Karlsøyfjord (intensively farmed area outside the protected zone) showed the highest abundance, the fish from Langfjord (lowfarming area inside the protected zone) showed the second highest abundance, and the lowest abundance was recorded in Eresfjord (non-farmed area inside the protected zone) (post hoc Mann-Whitney $U$-tests; p < $0.017)$. Mean abundance in the near-shore cages was 1.6, 0.4 and 0.1 lice per fish in Karlsøyfjord, Langfjord and Eresfjord, respectively. A significant difference in abundance was also found in the pelagic areas (Kruskal-Wallis test; $\mathrm{p}=0.000$ ): the fish in Karlsøyfjord had a significantly higher abundance than those in Eresfjord and Langfjord (post hoc Mann-Whitney $U$ tests; $\mathrm{p}<0.017$ ). Mean abundance in pelagic areas was 2.2 lice per fish in Karlsøyfjord, while abundance in Langfjord and Eresfjord were 0.13 and 0.15, respectively. Significant differences (Mann-Whitney $U$-test; $\mathrm{p}=0.028$ ) between near-shore and pelagic cages were found in Langfjord, but not in Eresfjord ( $p=0.338$ ) and Karlsøyfjord ( $\mathrm{p}=0.466)$.

Also, in the second trial (Fig. 5b), a significant difference in abundance was found in the 3 near-shore areas (Kruskal-Wallis test; $\mathrm{p}=0.000$ ). The abundance in fish in near-shore cages was highest in Karlsøyfjord (post hoc Mann-Whitney $U$-tests; $\mathrm{p}<0.017$ ), while there was no difference in abundance between fish in near-shore cages in Eresfjord and Langfjord ( $p=0.020$ ). Mean abundance was 2.3 lice per fish in near-shore cages in Karlsøyfjord, 0.2 lice per fish in near-shore cages in Langfjord and 0.0 lice per fish in near-shore cages in Eresfjord. There were also significant differences in abundance between the different pelagic areas

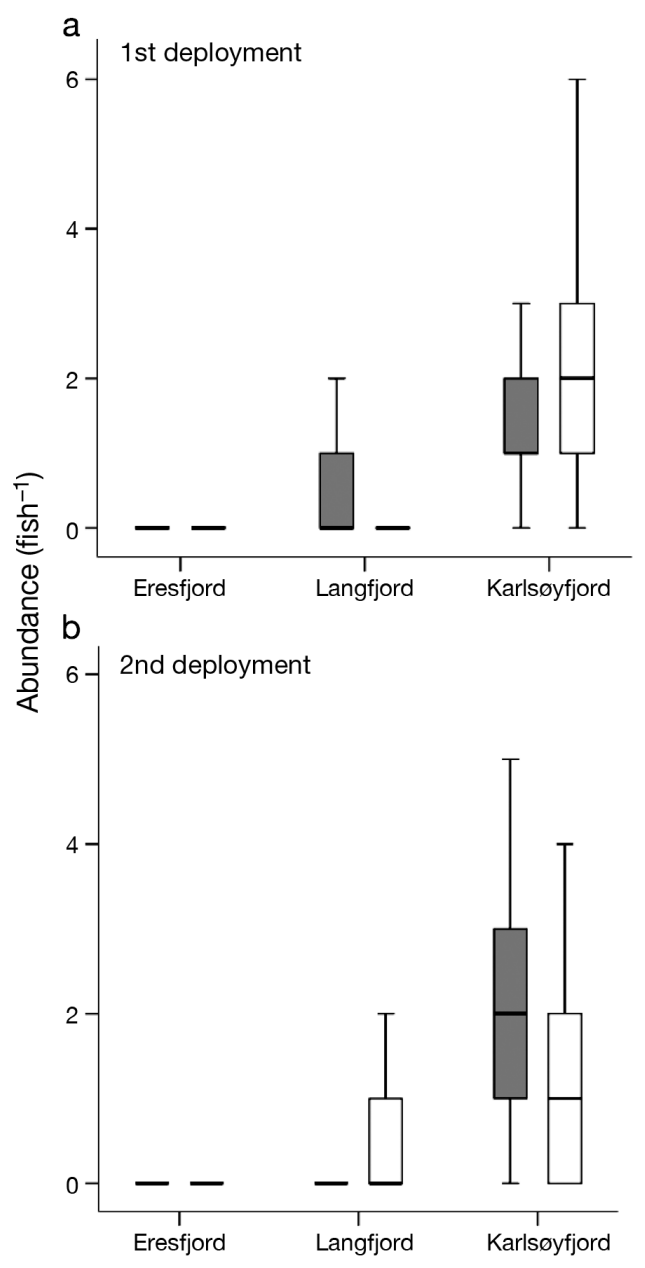

Fig. 5. Lepeophtheirus salmonis infecting Salmo salar. Boxand-whiskers plot showing the number of lice per fish in all fish held in sentinel cages (grey: littoral; white: pelagic) in Eresfjord, Langfjord and Karlsøyfjord in the 1st and 2nd deployment in 2004. Horizontal lines: median; bottom and top of boxes: 25th and 75th percentiles; whiskers: largest and smallest observed values that are not outliers

(Kruskal-Wallis test; $\mathrm{p}=0.000$ ): the lowest abundance was recorded in fish in pelagic cages in Eresfjord (post hoc Mann-Whitney $U$-tests; $\mathrm{p}<0.017$ ), while no difference was detected between Langfjord and Karlsøyfjord $(\mathrm{p}=0.20)$. A significant difference between pelagic and near-shore cages was found in Langfjord (MannWhitney $U$-test; $p=0.032$ ) and Karlsøyfjord ( $p=0.001)$, but not in Eresfjord ( $\mathrm{p}=0.357)$.

\section{Infection in fish farms inside and outside the protected zone}

The total number of farmed salmonids in the Romsdalsfjord system (in $90 \%$ of all fish farms) was higher outside than inside the protected area within each month both in 2003 and in 2004 (Fig. 6a,b). In 2003, the 
number of fish held in sea cages outside the protected area was approximately 4 times higher than that in Eresfjord. In 2004, 2 times more fish were held in cages outside than inside the protected area. The average number of sexually mature female lice per fish in the farms was not significantly different inside and outside the protective zone, either in 2003 or in 2004 (MannWhitney $U$-test; $\mathrm{p}=0.357$ ) (Fig. 6a,b).

\section{DISCUSSION}

The present study shows that the risk of salmon louse Lepeophtheirus salmonis infection differs between the farm-free Eresfjord, the intermediately farmed Langfjord and the intensively farmed Karlsøyfjord, all components of the Romsdalsfjord system. The observed difference is probably due to the different farming levels in the different zones of the fjord system, although other factors may also have contributed. Especially the lower salinity of Eresfjord might have acted as a natural protection against infective salmon lice stages (Heuch

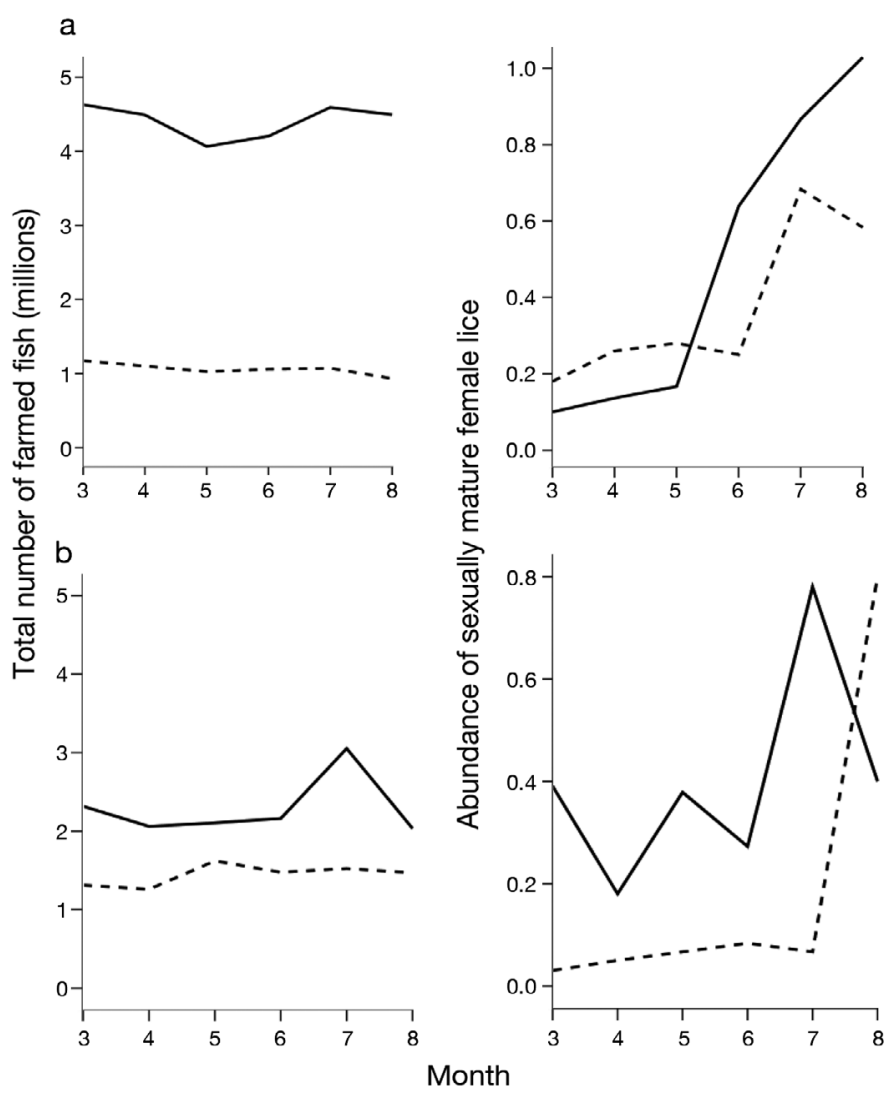

Fig. 6. Lepeophtheirus salmonis infecting Salmo salar. Total number of farmed salmonids and abundance of sexually mature female salmon lice infecting farmed salmonids in the Romsdalsfjord system in 2003 and 2004. Data are from March 3 to August 8 in (a) 2003 and (b) 2004. Broken line is inside and continuous line is outside the protective zone
1995) and, to some extent, contributed to reduces infection pressure in this area. The lower, but persistent, infection level in the protected zone of Langfjord and Eresfjord, compared to the unprotected zone in Karlsøyfjord, implies that there is a lower infection pressure in the protected area, but it also indicates that the protected zone is possibly too small and/or the permitted level of fish farm production too high to have the necessary effect (Heuch et al. 2005). Annual salmon louse epidemics have, by Norwegian authorities, been regarded as a major threat to long-term survival of wild salmonid populations in areas with intensive fish farming activity (DN 1993, Fiskeridirektoratet 1996, NOU 1999, DKMD 2006, DKF and Kystdepartementet 2009). As a precautionary approach, it was therefore decided to establish temporary protected zones (DN 1993, Fiskeridirektoratet 1996) and later Norwegian Salmon Fjords in a number of fjords with important salmon rivers (NOU 1999, DKMD 2002, 2006). In these fjords, no new salmon farms were allowed to be established, and those already established were given stricter operational regulations.

\section{Infection in wild sea trout}

The present study provides evidence of significantly lower infections of salmon lice in wild sea trout Salmo trutta inside compared to outside a temporary protected zone in the Romsdalsfjord system. Sea trout in Eresfjord had low to moderate infections during 2003 and 2004, and the infection level changed seasonally. The lowest prevalence and intensity were observed in spring each year, while the infection level peaked during summer, at magnitudes expected to negatively influence the most infected fish (e.g. Bjørn \& Finstad 1997, Wells et al. 2006, 2007, Finstad \& Bjørn in press), and levelled off in early autumn. In contrast to the infection level in Eresfjord, even lower intensities have generally been found in completely farm-free fjords in both northern (Bjørn \& Finstad 2002, Rikardsen 2004) and southern parts of Norway (Mo \& Heuch 1998, Schram et al. 1998). The results of the present study, therefore, indicate that establishment of small protected zones, with only limited fish farming activity, like this one in the Romsdalsfjord system, may be somewhat beneficial for sea trout inside the protected area. The protection against salmon louse infection is, however, limited compared to that a completely farm-free fjord, which implies that the zone is too small and/or that the farmed fish production allowed remains too high to have the necessary effect (Heuch et al. 2005).

In contrast to sea trout inside the protected zone, most of the sea trout captured outside the protected zone (Karlsøyfjord) had moderate to relatively high salmon 
louse infections in both years. Infections were generally low in May, increased relatively in June and July, but were reduced in late July and early August. The infection levels in the present study were, however, lower than those in previous studies focussed on other fjords with intensive fish farming in both western and northern Norway (Birkeland 1996, Bjørn et al. 2001). This may be a positive consequence of the recent measures (the national action plan against lice on wild and farmed salmonids, NA) taken by the industry and authorities to reduce the infection pressure on wild salmonids (Heuch et al. 2005, DKF and Kystdepartementet 2009, Asplin et al. in press), but might also be due to locality specific conditions (e.g. environmental conditions like salinity, temperature and current), a lower level of farming activity in the area, or new drugs (Ritchie \& Boxaspen in press). Louse infection levels previously reported in, e.g., Birkeland (1996) and Bjørn et al. (2001) will probably kill immature fish in seawater if the fish do not terminate the seawater phase and return prematurely to freshwater to delouse and restore physiological homeostasis (Grimnes \& Jakobsen 1996, Bjørn et al. 2001, Wagner et al. 2004, Wells et al. 2007). In the present study, premature return to freshwater was not investigated. However, infection levels expected to have significant negative physiological consequences for sea trout at sea (Bjørn \& Finstad 1997. Bjørn et al. 2001, Wagner et al. 2003, 2004, Wells et al. 2006, 2007) were frequently found, especially among the smallest fish, in Karlsøyfjord. This indicates that the total biomass of farmed salmon outside the protected zone may be so high that even the protective measures taken by the industry and authorities (NA) are not sufficient to reduce the infection pressure to a sustainable level (Heuch et al. 2005, DKF and Kystdepartementet 2009), or perhaps the protected zone is too small to provide the expected results.

\section{Infection in sentinel-caged Atlantic salmon smolts}

The study of sentinel caged Atlantic salmon Salmo salar smolts in different areas of the Romsdalsfjord system confirms the results from gill-netted sea trout. The infection risk, in both near-shore and pelagic cages, was significantly higher in the intensively farmed Karlsøyfjord (outside the protected zone), gradually decreased in the intermediately farmed Langfjord and was lowest in the farm-free Eresfjord (the latter both inside the protected zone). No clear difference between the near-shore and pelagic areas of the fjord were found, although significant differences between pelagic and near-shore cages were occasionally observed. The dispersal of infective louse stages in natural fjord systems is a complicated process, and little is yet known about the louse dispersal pattern. Infective stages are, however, expected to aggregate close to the surface (Heuch 1995, Heuch et al. 1995), avoid salinity <20 ppt (Heuch 1995, Bricknell et al. 2006) and aggregate in areas with turbulent water (Asplin et al. in press). They can also be transported very rapidly (Asplin et al. in press), over long distances (Costello 2006, Asplin et al. in press) and with a large variability in direction (Asplin et al. in press). Thorstad et al. (2004, 2007) have, in a telemetry study, compared the migratory routes of sea trout and Atlantic salmon post-smolts in the entire Romsdalsfjord system. Small sea trout tend to migrate in near-shore waters, close to the littoral zone, on both sides of the fjord. In contrast, Atlantic salmon post-smolts tend to migrate in more pelagic areas and more distant from shoreline. Since fish farms are usually located quite close to the littoral zone, it has been argued that the dispersal of infective stages of salmon lice may be more concentrated in these areas and expose sea trout to a higher infection risk. The results of the present study do not confirm this. On the contrary, infective louse stages seem to be distributed in both pelagic and littoral areas of the fjord, implying that both Atlantic salmon post-smolt and sea trout are at risk of infection.

However, a comparison of gill-netted sea trout with sentinel caged Atlantic salmon post-smolts showed, for the same time period and locality, that wild fish suffered significantly higher infections than caged fish. Wild sea trout sampled in Eresfjord at the end of both the first and second $14 \mathrm{~d}$ sentinel cage deployment (Weeks 21 and 24, respectively) had much higher infection levels than caged fish. Similar results were also found in Karlsøyfjord. In both cases, sentinel cages helped detect differences in infection pressure between areas, but they seemed to underestimate the infection level acquired in wild fish feeding in the same areas. In contrast to an actively swimming wild sea trout, sentinel caged Atlantic salmon are only at risk of infection by copepodids passing the cage. Feeding wild sea trout may also actively seek feeding habitats with abundant food, e.g. areas with turbulent current, where copepodids may also aggregate (Asplin et al. in press). However, the use of sentinel cages, provided that infection levels are better calibrated against levels in wild fish, is a promising method of investigating the risk of louse infection in fjords and coastal areas.

\section{Production and dispersal of louse infectious stages}

The risk of salmon louse infection inside and outside a protective fjord zone depends on complex relationships between different biological and physical factors. However, general agreement now exists, although direct conservative evidence is still lacking, that the 
risk of salmon louse infection is severely increased in areas with intensive fish farming activity (Bjørn et al. 2001, 2008, Butler \& Watt 2003, Gargan et al. 2003, Krkošek et al. 2005). The infection pressure in an area is therefore broadly assumed to be the product of the number of farmed hosts in the fjord and the number of mature female salmon lice per host (Heuch \& Mo 2001, Heuch et al. 2005). Calculations based upon estimates of the salmon louse abundance on farmed salmon in the Romsdalsfjord system showed that mean infections of sexually mature female lice per fish were not significantly different between the protected and unprotected zone. The total number of farmed hosts was, however, higher outside the protected zone both in 2003 and 2004. The production of salmon lice due to the increased fish farming activity must therefore have been between 2 to 4 times higher outside compared to inside the protected zone. This concurred with a significantly higher infection level on both wild sea trout and sentinel caged salmon outside the protected zone in both years. However, the increased risk of infection inside the protected zone, compared to in farm-free fjords, also implies that infective louse stages can disperse over long distances, given the right environmental conditions (Asplin et al. in press). Furthermore, the limited fish farm production allowed inside protected areas may still be sufficient to increase infection pressure in wild salmonids compared to in completely farm-free fjords, as most of the louse larvae do not travel very far (typically $<25 \mathrm{~km}$ ) (Asplin et al. in press).

\section{Area protection and risk of infection in wild salmonids}

To draw conclusions about the relationships between fish farms, protective zones and infection levels in wild salmonids, knowledge about wild fish ecology, as well as environmentally driven production and dispersal of infective louse stages inside the fjord system, is a prerequisite (Heuch et al. 2005). Wild sea trout in Norwegian fjords are generally found within a few kilometres of their native river mouth, and seldom migrate $>80 \mathrm{~km}$ away (Berg \& Berg 1987, Thorstad et al. 2004, Finstad et al. 2005). The large distance between the sampling site inside and outside the protected zone of the Romsdalsfjord system suggests it is reasonable to believe that the infection level in wild sea trout represents the true infection level in these areas. Under many circumstances, a salmon farm or salmon farming area can be considered as a point source of infection (Krkošek et al. 2005). Highest infection levels often occur in rivers and estuaries nearest fish farms (Bjørn et al. 2001, Butler \& Watt 2003, Gargan et al. 2003, Asplin et al. in press), but infectious louse stages can also be dispersed over long distances
(Heuch et al. 2005, Stien et al. 2005, Asplin et al. in press). The waterborne transmission of louse from farm sources to wild fish will strongly depend on both louse egg production and seawater circulation (Asplin et al. 2004, in press, Penston et al. 2008), as well as movement, survival and the duration of infective stages (Stien et al. 2005). The surprisingly high infection level in wild sea trout far inside the protected zone (Eresfjord) may, therefore, be explained by the horizontal dispersal of infective lice stages (Heuch et al. 2005, Asplin et al. in press), by the production of lice in fish farms inside the zone, or by sea trout undertaking long-distance seawater migrations (Berg \& Jonsson 1990) and spending parts of their seawater journey in higher risk areas (e.g. Karlsøyfjord). Thus, establishment of small protective zones with limited fish farm production inside a fjord area or fjord system cannot be the only consensus tool used to protect against the transmission of salmon louse from fish farms. Regionalized and synchronized delousing/fallowing of farmed fish inside the entire fjord system (Heuch et al. 2005), compulsory reporting of louse counts (NOU 1999), lower legal maximums for the mean number of louse per farmed fish (Heuch \& Mo 2001), or even lower allowed numbers of farmed fish are probably necessary to reduce the infections on wild salmonids to sustainable levels. Thus, the establishment of protective zones will also raise the question as to which wild species or populations should be protected. Atlantic salmon smolts swiftly migrate out of the fjord to the open ocean (Thorstad et al. 2004, Finstad et al. 2005, Davidsen et al. 2008), while the sea trout smolts seem to remain in littoral areas, often near their home river outlet (Berg \& Berg 1987, Thorstad et al. 2004, 2007, Finstad et al. 2005). A protective zone in inner fjord areas will probably increase the concentration of fish farms, and thereby also infection pressure, in outer fjord areas. Wild sea trout inside the protective zone will, to a certain degree, benefit from this. The situation is not necessarily the same for wild Atlantic salmon smolts, which have to pass intensively farmed areas to reach the open ocean, or for sea trout populations in outer fjord areas. The infection pressure in an area (Heuch \& Mo 2001) and the time period that a smolt is exposed to infective salmon louse (Sivertsgård et al. 2007) are the 2 main factors determining the risk of salmon louse infection in wild salmonid smolt. The time an Atlantic salmon smolt spends inside a protected zone with lower infection pressure must therefore be balanced by the time spent in a fjord area with higher infection pressure.

In conclusion, it can be questioned whether a protective zone like the one in the Romsdalsfjord system is large enough to give wild salmonids sufficient protection against salmon louse. Surprisingly, the relatively large temporary protected zone of Romsdalsfjord, Langfjord and Eresfjord was replaced in 2006 with the 
much smaller National Salmon Fjord of Isfjord (DKMD 2006) (see Fig. 1). Knowledge on the direct effects of area protection is, however, to a large extent, lacking; the present study is the first to address this issue in Norway. Establishments of the Norwegian Salmon Fjords have mostly been based on 'the precautionary principle'. The risk of initiating insufficient measurements for the protection of wild salmonids, as well as unnecessary regulations for the salmon farming industry, are therefore present. As is it difficult to extrapolate results from field studies from one area to another, it will be important to perform similar studies in other protected Norwegian fjord systems to evaluate the effect of area protection under different scenarios. These topics are of special interest in Norway, since the authorities have chosen area protection as one of the main measures to protect wild salmon (NOU 1999, DKMD 2002, 2006) from the negative effects of fish farming activity, but are also being discussed in other countries.

Acknowledgements. We are grateful to the staff at the Statkraft hatchery in Eresfjord, Bjørg Anne Vike, Petter Sira and Torbjørn Utigard, for extensive help and co-operation during the project. We acknowledge Tore Øverland for helping us out with the gill-netting. We also acknowledge Trond Haukebø at the County Governors Office, Inger Mette Hogstad at the Norwegian Food Safety Authority and Arve Slettvåg at the Fishery Directorate for their help. Thanks to Ivar Ellingsgård and family at Bolsøy, and finally special thanks to all the fish farmers in the Romsdalsfjord system who provided access to data. The study was financed by the European Commission Contract No. Q5RS-2002-00730 (SUMBAWS), the Norwegian Institute for Nature Research, Nofima Marine, IMR and Statkraft Energi, Norway.

\section{LITERATURE CITED}

Asplin L, Boxaspen K, Sandvik D (2004) Modelled distribution of salmon lice in a Norwegian fjord. ICES CM 2004/P:11

Asplin L, Boxaspen KK, Sandvik AD (in press) Modeling the distribution and abundance of planktonic larval stages of Lepeophtheirus salmonis in Norway. In: Jones S, Beamish $\mathrm{R}$ (eds) Salmon lice: an integrated approach to understanding parasite abundance and distribution. WileyBlackwell, Oxford

Berg OK, Berg M (1987) Migrations of sea trout, Salmo trutta L., from the Vardnes River in northern Norway. J Fish Biol 31:113-121

Berg OK, Jonsson B (1990) Growth and survival rates of the anadromous trout, Salmo trutta, from the Vardnes River northern Norway. Environ Biol Fishes 29:145-154

Birkeland K (1996) Salmon lice, Lepeophtheirus salmonis Krøyer, infestations and implications for anadromous brown trout, Salmo trutta L. PhD thesis, University of Bergen, Bergen

Bjørn PA, Finstad B (1997) The physiological effects of salmon lice infection on sea trout post smolts. Nord J Freshw Res 73:60-72

Bjørn PA, Finstad B (2002) Salmon lice, Lepeophtheirus salmonis (Krøyer), infestation in sympatric populations of Arctic char, Salvelinus alpinus (L.) and sea trout, Salmo trutta (L.), in areas near and distant from farms. ICES J Mar Sci 59:131-139

Bjørn PA, Finstad B, Kristoffersen R (2001) Salmon lice infection of wild sea trout and Arctic char in marine and freshwaters: the effects of salmon farms. Aquacult Res 32: 947-962

Bjørn PA, Finstad B, Nilsen R, Asplin L and others (2008) Nasjonal overvåkning av lakselusinfeksjon på ville bestander av laks, sjøørret og sjørøye i forbindelse med nasjonale laksevassdrag og laksefjorder. NINA Rapp 377:1-33

Blackburn J, Clarke WC (1987) Revised procedure for the 24 hour seawater challenge test to measure seawater adaptability of juvenile salmonides. Can Tech Rep Fish Aquat Sci 1515:1-39

Boxaspen K, Hay D, Finstad B (2007) Salmon louse (Lepeophtheirus salmonis). In: Raynard R, Wahli $\mathrm{T}$, Vatsos I, Mortensen S (eds) Review of disease interactions and pathogen exchange between farmed and wild finfish and shellfish in Europe. VESO, Oslo, p 85-97

Bricknell IR, Dalesman SJ, O'Shea B, Pert CC, Luntz AJM (2006) Effect of environmental salinity on sea lice Lepeophtheirus salmonis settlement success. Dis Aquat Org 71: 201-212

> Bush AO, Lafferty KD, Lotz JM, Shostak AW (1997) Parasitology meets ecology on its own terms: Margolis et al. revised. J Parasitol 83:575-583

Butler JRA, Watt J (2003) Assessing and managing the impacts of marine salmon farms on wild Atlantic salmon in western Scotland: identifying priority rivers for conservation. In: Mills D (ed) Salmon at the edge. Blackwell Science, Oxford, p 93-118

> Costello MJ (2006) Review. Ecology of sea lice parasitic on farmed and wild fish. Trends Parasitol 22:475-483

> Costelloe J, Costelloe M, Roche N (1995) Variation in sea lice infestation on Atlantic salmon smolts in Killary Harbour, West Coast of Ireland. Aquacult Int 3:379-393

> Davidsen JG, Plantalech Manel-la N, Økland F, Diserud OH and others (2008) Changes in swimming depths of Atlantic salmon post-smolts relative to light density. J Fish Biol 73:1065-1074

DKF and Kystdepartementet (2009) Strategi for en miljømessig bærekraftig havbruksnæring. Det Kongelige Fiskeriog Kystdepartementet, Oslo

DKMD (Det kongelige miljødepartement) (2002) Om opprettelsen av nasjonale laksevassdrag og laksefjorder. St. prp. nr. 79, Det kongelige miljødepartement, Oslo

DKMD (2006) Om vern av villaksen og ferdigstilling av nasjonale laksevassdrag og laksefjorder (Protection of wild Atlantic salmon and completion of national salmon fjords). St. prp. nr. 32, Det kongelige miljødepartement, Oslo

DN (Direktoratet for naturforvaltning) (1993) Fagseminar om lakselusproblematikken og tiltaksstrategier. DN-notat 1993-3, Direktoratet for naturforvaltning, Trondheim

Finstad B, Bjørn PA (in press) Present status and implications of salmon lice on wild salmonids in Norwegian coastal zones. In: Jones S, Beamish R (eds) Salmon lice: an integrated approach to understanding parasite abundance and distribution. Wiley-Blackwell, Oxford

Finstad B, Bjørn PA, Grimnes A, Hvidsten NA (2000) Laboratory and field investigations of salmon lice (Lepeoptheirus salmonis Krøyer) infestation on Atlantic salmon (Salmo salar L.) post smolts. Aquacult Res 32:947-962

Finstad B, Økland F, Thorstad EB, Bjørn PA, McKinley RS (2005) Migration of hatchery-reared Atlantic salmon and wild anadromous brown trout postsmolts in a Norwegian fjord system. J Fish Biol 65:1-11

Finstad B, Boxaspen KK, Asplin L, Skaala Ø (2007) Lakselus- 
interaksjoner mellom oppdrettsfisk og villfisk-Hardangerfjorden som et modellområde. In: Dahl E, Hansen PK, Haug T, Karlsen Ø (eds) Kyst og havbruk 2007. Særn. 22007, Fisken og havet, Bergen, p 69-73

Fiskeridirektoratet (1996) Evaluering av midlertidige sikringssoner for laksefisk (1989-94): forslag til nye prinsipper for soner i sårbare områder for vill laksefisk, retningslinjer for etablering og drift av oppdrettsanlegg i sonene, samt forslag til geografiske avgrensinger. Fiskeridirektoratet, Bergen

Gargan PG, Tully O, Poole WR (2003) Relationship between sea lice infestations, sea lice productions and sea trout survival in Ireland, 1992-2001. In: Mills (ed) Salmon at the edge. Blackwell Science, Oxford, p 119-135

Grimnes A, Jakobsen P (1996) The physiological effects of salmon lice (Lepeophtheirus salmonis Krøyer) infection on post smolt of Atlantic salmon (Salmo salar). J Fish Biol 48:1179-1194

Heuch PA (1995) Experimental evidence for aggregation of salmon louse copepodids, Lepeophtheirus salmonis, in step salinity gradients. J Mar Biol Assoc UK 75:927-939

Heuch PA, Mo TA (2001) A model of salmon louse production in Norway: effects of increasing salmon production and public management measures. Dis Aquat Org 45:145-152

Heuch PA, Parsons A, Boxaspen K (1995) Diel vertical migration: a possible host-finding mechanism in salmon louse (Lepeophtheirus salmonis) copepodids? Can J Fish Aquat Sci 52:681-689

Heuch PA, Bjørn PA, Finstad B, Holst JC, Asplin L, Nilsen F (2005) A review of the Norwegian 'National Action Plan Against Salmon Lice on Salmonids': the effect on wild salmonids. Aquaculture 246:79-92

Jensen AJ, Bremset G, Finstad B, Hvidsten NA and others (2008) Fiskebiologiske undersøkelser i Auravassdraget. Årsrapport 2007. NINA Rapport 327 (in Norwegian with English summary)

> Johnson SC, Albright LJ (1991) Development, growth, and survival of Lepeophtheirus salmonis (Copepoda: Caligidae) under laboratory conditions. J Mar Biol Assoc UK 71:425-436

Krkošek M, Lewis MA, Volpe JP (2005) Transmission dynamics of parasitic sea lice from farm to wild salmon. Proc R Soc Biol Sci 272:689-696

Krkošek M, Ford JS, Morton A, Lele S, Myers RA, Lewis MA (2007) Declining wild salmon populations in relation to parasites from farm salmon. Science 318:1772-1775

Mo TA, Heuch PA (1998) Occurrence of Lepeophtheirus salmonis (Copepoda: Caligidae) on sea trout (Salmo trutta) in the inner Oslo Fjord, south-eastern Norway. ICES J Mar Sci 55:176-180

NOU (Norges Offentlige Utredninger) (1999) Til laks åt alle kan ingen gjera? Om årsaker til nedgangen i de norske villlaksbestandene of forslag til strategier og tiltak for å bedre situasjonen, Statens forvaltningstjeneste. Norges offentlige utredninger 9, Miljøverndepartementet, Oslo (in Norwegian with English summary)

Penston MJ, Millar CP, Zuur A, Davies IM (2008) Spatial and temporal distribution of Lepeophtheirus salmonis (Krøyer) larvae in a sea loch containing Atlantic salmon, Salmo salar L., farms on the north-west coast of Scotland. J Fish Dis 31:361-371

Portz DE, Woodley CM, Cech JJ (2006) Stress-associated impacts of short-term holding on fishes. Rev Fish Biol Fish $16: 125-170$

Rikardsen AH (2004) Seasonal occurrence of sea lice Lepeophtheirus salmonis on sea trout Salmo trutta in two North Norwegian fjords. J Fish Biol 65:711-722

Rikardsen AH, Diserud OH, Malcolm Elliott J, Dempson BJ,

Editorial responsibility: Tim Dempster,

Trondheim, Norway
Sturlaugsson J, Jensen AJ (2007) The marine temperature and depth preferences of Arctic charr (Salvelinus alpines) and sea trout, as recorded by data storage tags. Fish Oceanogr 16:436-447

Ritchie $\mathrm{G}$, Boxaspen KK (in press) Salmon lice management on farmed salmon-Norway. In: Jones S, Beamish R (eds) Salmon lice: an integrated approach to understanding parasite abundance and distribution. Wiley-Blackwell, Oxford

Schram TA (1993) Supplementary descriptions of the developmental stages of Lepeophtheirus salmonis (Krøyer, 1837) (Copepoda: Caligidae). In: Boxhall GA, Defaye D (eds) Phatogens of wild and farmed fish. Sea Lice. Ellis Horwood, New York, NY, p 30-47

Schram TA, Knutsen JA, Heuch PA, Mo TA (1998) Seasonal occurrence of Lepeophtheirus salmonis and Caligus elongatus (Copepoda: Caligidae) on sea trout (Salmo trutta), off southern Norway. ICES J Mar Sci 55:163-175

- Scott ME (1987) Temporal changes in aggregation: a laboratory study. Parasitology 94:583-595

> Sigholt T, Finstad B (1990) Effect of low temperature on seawater tolerance in Atlantic salmon (Salmo salar) smolts. Aquaculture 84:167-172

> Sivertsgård R, Thorstad EB, Økland F, Finstad B and others (2007) Effects of salmon lice infection and salmon lice protection on fjord migrating Atlantic salmon and brown trout post-smolts. Hydrobiologia 582:35-42

Stien A, Bjørn PA, Heuch PA, Elson DA (2005) Population dynamics of salmon lice Lepeophtheirus salmonis on Atlantic salmon and sea trout. Mar Ecol Prog Ser 290: 263-275

> Thorstad EB, Økland F, Finstad B, Sivertsgård R, Bjørn PA, McKinley RS (2004) Migration speeds and orientation of Atlantic salmon and sea trout post-smolts in a Norwegian fjord system. Environ Biol Fishes 71:305-311

Thorstad EB, Økland F, Finstad B, Sivertsgård R, Plantalech N, Bjørn PA, McKinley RS (2007) Fjord migration and survival of wild and hatchery-reared Atlantic salmon and wild brown trout post-smolts. Hydrobiologia 582: 99-107

Tully O, Nolan DT (2002) A review of the population biology and host-parasite interactions of the sea louse Lepeophtheirus salmonis (Copepoda: Caligidae). Parasitology 124:165-182

> Wagner GN, McKinley RS, Bjørn PA, Finstad B (2003) Physiological impact of sea lice on swimming performance of Atlantic salmon. J Fish Biol 62:1000-1009

Wagner GN, McKinley RS, Bjørn PA, Finstad B (2004) Shortterm freshwater exposure benefits sea lice-infected Atlantic salmon. J Fish Biol 64:1593-1604

Wagner GN, Fast MD, Johnson SC (2008) Physiology and immunology of Lepeophtheirus salmonis infections of salmonids. Trends Parasitol 24:176-183

Wedemeyer GA (1997) Rearing conditions: effects on fish in intensive culture. In: Iwama GK, Pickering AD, Sumpter JP, Schreck CB (eds) Fish stress and health in aquaculture. Soc Exp Biol Seminar Series 62. University Press, Cambridge, p 35-71

Wells A, Grierson CE, MacKenzie M, Russon IJ and others (2006) Physiological effects of simultaneous, abrupt seawater entry and sea lice (Lepeophtheirus salmonis) infestation of wild, sea-run brown trout (Salmo trutta) smolts. Can J Fish Aquat Sci 63:2809-2821

- Wells A, Grierson CE, Marshall L, MacKenzie M and others (2007) Physiological consequences of 'premature freshwater return' for wild sea-run brown trout (Salmo trutta) postsmolts infested with sea lice (Lepeophtheirus salmonis). Can J Fish Aquat Sci 64:1360-1369

Submitted: February 25, 2011; Accepted: April 18, 2011

Proofs received from author(s): May 21, 2011 